\title{
The Economic and Trade Cooperation of China with Countries along the Belt and Road
}

\author{
Liu Zhongyun \\ Economics and Statistics Sorting \\ Xing Zhi College of Xi'an University of Finance and Economics \\ Xi'an, China \\ E-mail: 752668638@qq.com
}

\begin{abstract}
From September 2013 Chinese President Xi Jinping proposed The Belt and Road, the strategic vision has been two years. China and countries of The Belt and Road economic and trade cooperation has become one of the focuses of attention. Based on this, this paper analyzes the current situation of economic and trade cooperation between China and along the countries of The Belt and Road. This article first introduced the Belt and Road related countries and province, city and regional of China in map and table form. And then using statistical data from China's Ministry of Commerce, this article analyzed the country's total trade, foreign direct investment, foreign direct investment, foreign direct investment, the use of foreign investment and foreign contracted projects from 2014 to the first half of 2015. This article analyzed the economic contribution of China's provinces to countries along the Belt and Road, the results show that the degree of trade dependence between China and the countries along the Belt and Road deepened, while showing uneven. And then get a conclusion that the economic and trade exchanges and economic integration continues to deepen of China with countries along the Belt and Road after the strategic of the Belt and Road.
\end{abstract}

Keywords-The Belt and Road; Economic and Trade; Total Trade; Absorb Foreign Capital; Outward Foreign Direct Investment;

\section{INTRODUCTION}

Since Chinese President Xi Jinping put forward the Belt and Road, the positive response has been obtained along the countries, thus promoting the further development of trade and investment cooperation between China with countries along the Belt and Road.

In this paper, we choose the countries along the Belt and Road of 5 countries of Central Asia, Mongolia and Russia, 11 countries in Southeast Asia, 19 countries in central Eastern and European, 8 countries of South Asia and 19 countries in West Asia and the Middle East, etc, the paper uses the data of 2014 to 2015 in the first half of the year, and analyzes the trade and investment of China and these countries and regions.

\section{GEOGRAPHY AND ECONOMIC TRADE OF THE BELT AND ROAD}

When Chinese President Xi Jinping visited Central Asia and Southeast Asia in September and October of 2013, he raised the initiative of jointly building the Silk Road Economic Belt and the 21st-Century Maritime Silk Road (hereinafter referred to as the Belt and Road). It mainly included ${ }^{[1]}$ : The Belt and Road run through the continents of Asia, Europe and Africa, connecting the vibrant East Asia economic circle at one end and developed European economic circle at the other, and encompassing countries with huge potential for economic development. The Silk Road Economic Belt focuses on bringing together China, Central Asia, Russia and Europe (the Baltic); linking China with the Persian Gulf and the Mediterranean Sea through Central Asia and West Asia; and connecting China with Southeast Asia, South Asia and the Indian Ocean. The 21st-Century Maritime Silk Road is designed to go from China's coast to Europe through the South China Sea and the Indian Ocean in one route, and from China's coast through the South China Sea to the South Pacific in the other.

Details are shown in figure $1^{[2]}$ and table 1.

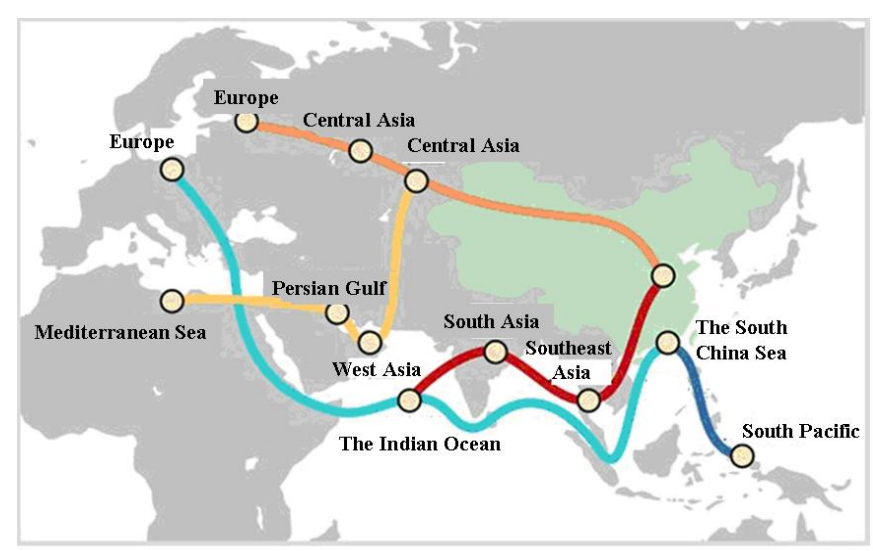

Figure1. Countries of the Belt and Road Initiative Area

The Belt and Road throughout Eurasia, China - Central Asia, West Asia, Mongolia and Russia and other major economic corridor radiation, involving about 65 countries. The total population of about 4400000000 of countries along the Belt and Road, about 21 of the total economy, accounting for about $63 \%$ and $29 \%$ of the world, respectively ${ }^{[3]}$.

According to the Asian Development Bank's estimates, in 2020, the annual investment in the Asian region for the construction needs of $\$ 730000000000$. 
TABLE I. COUNTRIES THE BELT AND ROAD INITIATIVE AREA

\begin{tabular}{|c|l|}
\hline Map plate & $\begin{array}{l}\text { The countries along the Belt and } \\
\text { Road }\end{array}$ \\
\hline Central Asian & $\begin{array}{l}\text { Kazakhstan, Kyrgyzstan, Tajikistan, } \\
\text { Uzbekistan and Turkmenistan }\end{array}$ \\
\hline $\begin{array}{c}\text { Mongolia and } \\
\text { Russia }\end{array}$ & Mongolia, Russia \\
\hline $\begin{array}{c}\text { Southeast } \\
\text { Asian }\end{array}$ & $\begin{array}{l}\text { Vietnam, Laos, Kampuchea, Thailand, } \\
\text { Malaysia, Singapore, Indonesia, Brunei, } \\
\text { Philippines, Burma, East Timor }\end{array}$ \\
\hline South Asian & $\begin{array}{l}\text { India, Pakistan, Bangladesh, } \\
\text { Afghanistan, Nepal, Bhutan, Sri Lanka, } \\
\text { Maldives }\end{array}$ \\
\hline $\begin{array}{l}\text { Middle East } \\
\text { and European }\end{array}$ & $\begin{array}{l}\text { Poland, the Czech Republic, Slovakia, } \\
\text { Bungary, Slovenia, Croatia, Romania, } \\
\text { Macedonia, Bosnia and Herzegovina, } \\
\text { Albania, Estonia, Lithuania, Latvia, } \\
\text { Ukraine, Belarus, Moldova }\end{array}$ \\
\hline $\begin{array}{l}\text { West Asia and } \\
\text { the Middle } \\
\text { East }\end{array}$ & $\begin{array}{l}\text { Turkey, Iran, Syria, Iraq, the United } \\
\text { Arab Emirates, Saudi Arabia, Qatar, } \\
\text { Bahrain, Kuwait, Lebanon, Oman, } \\
\text { Yemen, Jordan, Israel, Armenia, } \\
\text { Georgia, Azerbaijan, Egypt }\end{array}$ \\
\hline
\end{tabular}

\section{ANALYSIS OF THE TRADE BETWEEN CHINA AND COUNTRIES ALONG THE BELT AND ROAD IN 2014}

\section{A. Analysis of Total Trade}

The total trade volume between China with countries along the Belt and Road in 2001 was $\$ 8400000000$, in 2014 was $\$ 112000000000$, an increase of about 14 times. Among them with the total trade of Southeast Asian countries reached $\$ 48030000000$, accounting for $43.9 \%$, West Asia and middle East of the 19 countries, the total trade accounted for $28.2 \%$. ${ }^{[4]}$

In 2014, China's foreign capital inflows to $\$ 128000000000$, foreign investment \$140000000000.

China has surpassed Japan as the largest foreign investor in Asia and the world's third largest foreign investor in Asia for the first time. In 2014, China to Asian, Africa, Russia, India and other countries of the bilateral trade growth rate was significantly higher than the average growth rate. China has become the largest trading partner of ASEAN in the five years; bilateral trade volume is expected to reach $\$ 1000000000000$ by 2020 . In the next ten years, China and countries along the Belt and Road in the export share is expected to increase to $1 / 3$.

\section{B. Maintaining the Integrity of the Specifications \\ Analysis of Outward Foreign Direct Investment}

Chinese enterprises have carried out direct investment in 48 countries along the Belt and Road. Total investment of $\$ 7050000000$, an increase of $22 \%{ }^{[5]}$, this investment accounts for $15.3 \%$ of China's non - financial foreign direct investment. China's investment is mainly aimed at countries such as Singapore, Indonesia, Laos, Russia, Kazakhstan and Thailand.The above analysis shows that the trade relations between China with the country's of the
Belt and Road have become more and more closely, since the Belt and Road proposed.

\section{ECONOMIC AND TRADE SITUATION OF CHINA WITH COUNTRIES OF THE BELT AND ROAD IN JUNE, IN 2015}

Along with the strategy of the Belt and Road, since 2015, China has been working closely with the national economic and trade cooperation along with countries of the Belt and Road. Analysis of the data from the first quarter and the first half of 2015

\section{A. The National Economic and Trade Cooperation of} China with Countries of the Belt and Road in the First Quarter of 2015

At a routine press conference, the spokesman Shen Da n-yang of Chinese Ministry of Commerce said that ${ }^{[6]}$ China and the countries along with of the Belt and Road of bilateral trade volume of $\$ 236000000000$, accounting for $26 \%$ of the total import and export volume, among them, China's exports of $\$ 144500000000$, an increase of $10 \%$, accounting for $28 \%$ of China's total exports, a substantial lead in the overall export growth. At the same time, China imported $\$ 91500000000$ from the country, accounting for $23.4 \%$ of China's total imports, in the first quarter of 2015.

\section{1) The Use of Foreign Investment}

The countries along with of the Belt and Road to set up foreign investment enterprises 457 in China, an increase of $18.4 \%$, the actual amount of foreign investment $\$ 1680000000$. Among them, Mongolia and Russia and Central Asian countries in China's real investment in the overall growth of more than 1 times, and Central and Eastern Europe, Western Asia and North Africa region of China's real investment amount increased more than 4 times.

\section{2) Outbound Investment}

China to the countries along with of the Belt and Road to achieve non financial direct investment 2560000000 U.S. dollars, accounting for $9.9 \%$ of total foreign direct investment over the same period; of which Singapore, Indonesia and Laos were among the top three.

3) Foreign Contracted Project

In the foreign contract engineering business, China's business and along the way along the country signed a contract amount of $\$ 15200000000$, completed a turnover of $\$ 7.6 \%$, an increase of 14000000000 and $10.3 \%$, respectively.

\section{B. Economic and Trade Situation of China with} Countries of the Belt and Road in June, 2015

August 4, 2015, China's Ministry of Commerce held a regular press conference, at the meeting, spokesman Danyang Shen introduced the national economic and trade cooperation of China with countries of the Belt and Road in the first half of $2015^{[7]}$.

\section{1) Foreign Trade}

The bilateral trade amounted to $\$ 485370000000$ of China with countries of the Belt and Road, accounting for $25.8 \%$ of China's total imports and exports over the same period, among them, China's exports of $\$ 295770000000$, up to $1.9 \%$ and account for $27.6 \%$ of total exports. On the other hand, China imported $\$ 189600000000$, down from $20.9 \%$, accounting for $23.4 \%$ of total imports 


\section{2) Absorb Foreign Capital}

The countries of the Belt and Road to invest in China to set up enterprises 948 , an increase of $10.62 \%$; the actual amount of foreign investment for China is $\$ 3670000000$, an increase of $4.15 \%$. From the perspective of the investment industry, Table 2 lists the industry and an increase in the growth rate.

TABLE II. AN INDUSTRY OF RAPID INVESTMENT GROWT

\begin{tabular}{|l|c|c|c|}
\hline & $\begin{array}{c}\text { Transmission of } \\
\text { information }\end{array}$ & $\begin{array}{c}\text { Computer, } \\
\text { software } \\
\text { industry }\end{array}$ & $\begin{array}{c}\text { Finance, } \\
\text { leasing and } \\
\text { business } \\
\text { services }\end{array}$ \\
\hline Growth rate & $116.54 \%$ & $1262.15 \%$ & $150.02 \%$ \\
\hline
\end{tabular}

From the national sources, Table 3 lists some of the countries where they actually put an increase in the number of foreign investment.

TABLE III. COUNTRIES WITH HIGH GROWTH IN FOREIGN INVESTMENT

\begin{tabular}{|c|c|c|c|c|l|}
\hline & Malaysia & $\begin{array}{c}\text { Saudi } \\
\text { Arabia }\end{array}$ & Poland & Russia & $\begin{array}{l}\text { The } \\
\text { Republic } \\
\text { of } \\
\text { Slovakia }\end{array}$ \\
\hline Growth rate & $135.51 \%$ & $697.27 \%$ & $3621.92 \%$ & $129.36 \%$ & $196.67 \%$ \\
\hline
\end{tabular}

\section{3) Outward Foreign Direct Investment}

Chinese companies for the 48 countries made a direct investment, the total investment of $\$ 7050000000$, an increase of $22 \%$, these amounts account for $15.3 \%$ of China's non financial foreign direct investment.

The investment mainly to Singapore, Indonesia, Laos, Russia, Kazakhstan and Thailand, etc.

\section{4) Foreign Contracted Projects Conclusions}

Chinese enterprises to undertake foreign projects a total of 1401 and the newly signed contract amount to $\$ 37550000000$, in the same period of the contract amount of $43.3 \%$ and an increase of $16.7 \%$. The projects are mainly in the fields of electrical engineering, communication engineering, housing construction, transportation, petroleum and chemical engineering. Turnover has been completed for \$29700000000, accounted for $44 \%$ of the turnover of the same period, an increase of $5.4 \%$.

\section{5) Outsourcing of Services}

Chinese enterprises with countries of the Belt and Road has signed a contract of service outsourcing contract amount of $\$ 7060000000$, the amount has been executed for $\$ 4830000000$, an increase of $17 \%$ and $4.1 \%$, respectively.

\section{ANALYSIS OF THE ECONOMIC CONTRIBUTION OF CHINA'S PROVINCES TO THE COUNTRIES OF THE BELT AND ROAD CONCLUSIONS}

In China, the focus of the planning of the Belt and Road, including 18 provinces, such as figure 8 and table 4 shows ${ }^{[8]}$

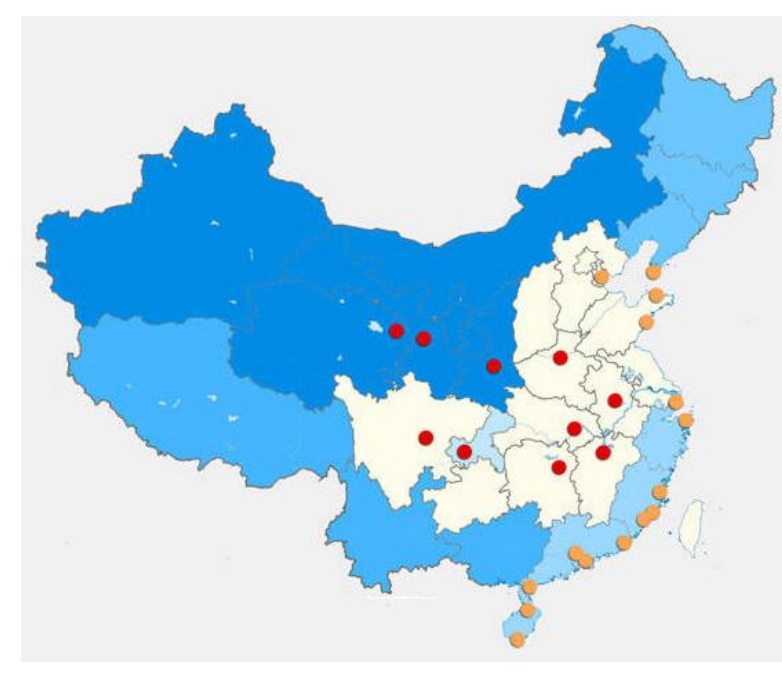

Figure2. China's Provinces and Cities in the Area of the Belt and Road

TABLE IV. CHINA'S PROVINCES AND CITIES IN THE AREA OF THE BELT AND ROAD

\begin{tabular}{|c|c|c|}
\hline Area & $\begin{array}{c}\text { Name of the } \\
\text { province and the } \\
\text { city }\end{array}$ & $\begin{array}{c}\text { The color } \\
\text { shown in } \\
\text { Figure 2. }\end{array}$ \\
\hline $\begin{array}{c}\text { 6 provinces in the } \\
\text { Northwest of China } \\
\text { Xinjiang, Shanxi, } \\
\text { Gansu, Ningxia, } \\
\text { Qinghai, Inner } \\
\text { Mongolia }\end{array}$ & \\
\hline $\begin{array}{c}3 \text { provinces in the } \\
\text { Northeast of China }\end{array}$ & $\begin{array}{c}\text { Heilongjiang, Jilin, } \\
\text { Liaoning }\end{array}$ & \\
\hline $\begin{array}{c}3 \text { provinces in } \\
\text { Southwest of China }\end{array}$ & $\begin{array}{c}\text { Guangxi, Yunnan } \\
\text { and Tibet }\end{array}$ & \\
\hline $\begin{array}{c}\text { provinces and } 1 \\
\text { cities in the } \\
\text { Southeast of China } \\
\text { Guangdong, } \\
\text { Zhejiang, Hainan } \\
\text { and Shanghai City }\end{array}$ & \\
\hline $\begin{array}{c}\text { Inland region of } \\
\text { China }\end{array}$ & \begin{tabular}{c} 
Chongqing City \\
\hline the city clusters
\end{tabular} & \\
\hline $\begin{array}{c}\text { Coastal cities and } \\
\text { ports }\end{array}$ & \\
\hline
\end{tabular}

\section{A Analysis of China's Foreign Investment in 2014}

China's total foreign investment reached $\$ 116000000000$ in 2014 , If you add from the third party financing after re investment, in 2014, China's total foreign investment of about $\$ 140000000000$. China's total foreign investment exceeds the total amount of foreign investment in China, China has become a net exporter of capital.2014 China's foreign investment data shown in Figure $3^{[9]}$. 


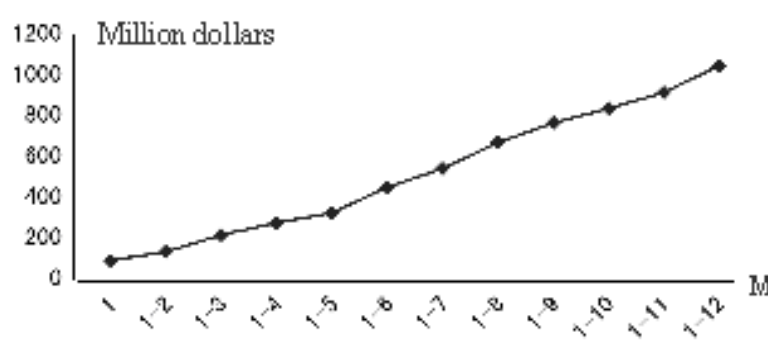

Figure3. China's Foreign Investment Data in 2014

In 2014, China's total non-financial direct investment was $\$ 102890000000$, an increase of $14.1 \%$; the actual use of foreign investment was 19560000000, an increase of $1.7 \%$. For the first time, China's bilateral investment approach to balance.

\section{$B$ Analysis of China's Foreign Investment to the Key} Countries of the Belt and Road in the First Half of 2015

The first quarters of 2015, total import and export volume reached $\$ 27800000000$ of Guangdong province to the key countries of the Belt and Road, an increase of $6.5 \%$. Total import and export volume of Jiangsu province to the key countries of the Belt and Road was \$26400000000, of which exports $\$ 17800000000$, an increase of $7 \%$.

Total import and export volume of Zhejiang province to the key countries of the Belt and Road was \$ 23360000000, of which exports \$ 19400000000, an increase of $16 \%$.

Total import and export volume of Fujian province to the key countries of the Belt and Road was $\$ 10100000000$, an increase of $3.6 \%{ }^{[9]}$.

In the first half of 2015, From the regional distribution of foreign investment, the higher the proportion of investment is Shanghai, Jiangsu and Shandong provinces, the proportion was $22.24 \%, 16.04 \%$ and $7.84 \%{ }^{[\hbar]}$.

\section{CONCLUSION}

From the above analysis, a conclusion can be drawn that the economic and trade exchanges and economic integration continues to deepen of China with countries along the Belt and Road After the strategic of the Belt and Road. Therefore, we believe that the construction of he Belt and Road is not only conducive to China's Montldevelopment, but also conducive to the growth of countries along the line and the global economy. The number of countries involved in The Belt and Road are large and a wider range, which requires China to take part in the strategy that must be based on the need to combine common interests, to seek a breakthrough in the construction of The Belt and Road.

\section{REFERENCES}

[1] The National Development and Reform Commission, Ministry of Foreign Affairs, and Ministry of Commerce of the People's Republic of China.Vision and proposed actions outlined on jointly building Silk Road Economic Belt and 21st-Century Maritime Silk Road[R].. 28,3,2015

[2] http://www.czgu.com/a/guoji/waimei/2015/0622/68509.html

[3] Hucheng Gao.The Belt and Road to build a new pattern of economic and trade cooperation $[\mathrm{J}]$. Finance and Accounting for International Commerce,2014(6): 5-7

[4] Zou J L,Liu C L, Yin G Q, et al. Spatial patterns and economic effects of China's trade with countries along the Belt and Road[J]. Progress in Geography, 2015.34.(5): 598-605.

[5] Han X F, Luo X W, Zou JH. Trade Cooperation competitivenes and complementarities of China and West Asia under the background of Silk Road Economic Belt and Maritime Silk Road strategy[J].World Economy Studies, 2015 (3): 89-98.

[6] Song binbin.The Belt and Road to boost China's foreign economic and trade cooperation [J].Machine manufacturing, 2015(6):14

[7] The print reports. Introduction of the national economic and trade cooperation of China with the countries of the Belt and Road in the first half of 2015[J]. International Project Contracting \& Labour 2015(8):.99

[8] http://www.stdaily.com/nypd/ywjj/201504/t20150401_1016968.sht $\mathrm{ml}$

[9] http://finance.eastmoney.com/news/1347,20150122470705115.htm 